\title{
Two-Dimensional Gel Electrophoresis of Protein profile from Groundnut (Arachis hypogaea sp. Virginia) at Flower Development Stage
}

\author{
Nimita Umretiya ${ }^{1 *}$, Hitesh Jasani ${ }^{2}$, Nilam Tulsani ${ }^{1}$, Abhijeeta Nandha ${ }^{1}$ \\ and B.A. Golakiya ${ }^{1}$ \\ ${ }^{1}$ Department of Biotechnology, Junagadh Agricultural University, \\ Junagadh-362001, Gujarat, India \\ ${ }^{2}$ College of Computer, Science and Information Technology, \\ Junagadh-362015, Gujarat, India \\ *Corresponding author
}

A B S T R A C T

Keywords

Two-Dimensional

Electrophoresis (2-

DE), Protein profile,

Groundnut, Arachis

hypogaea, Protein

extraction

\section{Article Info}

Accepted:

24 September 2018

Available Online:

10 October 2018
Protein is play critical role in flower development. Profiles of total flower development proteins isolated from different stages (Bud, Flower and Peg) peanut cultivar GJG-22, were studied using two-dimensional gel electrophoresis. Protein is extracted by trichloro acetic acid/acetone precipitation method. Comparative analysis was carried out of spots identified using platinum master software at three different flower stages. Protein revealed that total 9193 protein spots with the $\mathrm{pH}$ range 4 - 7 and 23-312 $\mathrm{kDa}$ range recorded. Out of 9193 spots, maximum 3413 spots were found in $\mathrm{pH}$ range 6 - 7 in groundnut samples. Proteomic analysis reveals the translational products of gene expression of plant during flowering stage.

\section{Introduction}

The most precarious step in any proteomics study is sample extraction and preparation. In this regard, proteomic analysis of plant tissues involves a number of practical challenges that are typically more problematic than with other samples. In addition to having relatively low protein concentrations, plant tissues are often higher in proteases enzyme and materials that severely restrict with downstream protein purification and analysis, including cell wall and storage polysaccharides, phenolic mixtures, lipids and a wide-ranging of secondary metabolites (Granier, 1988; Tsugita and Kamo, 1999).

Groundnut or peanut (Arachis hypogaea L.) is one of the principal economic crops of the world (Cobb and Johnson, 1973). It is most popular and universal legume crops, cultivated in more than 100 countries. Groundnut plays an important role in the agricultural and industrial economy of the country. Arachis 
hypogaea has the widest distribution of any Arachis species. More than half of the production area that accounts for $70 \%$ of the groundnut growing area falls under arid and semi-arid regions (Reddy et al., 2003). It is a rich source of oil $(49.24 \mathrm{~g} / 100 \mathrm{~g})$, protein $(25.80 \mathrm{~g} / 100 \mathrm{~g})$, carbohydrates (16.13 g/100 $\mathrm{g}$ ), minerals, fiber and vitamins (USDA National Nutrient database).

In groundnuts, the basic reproductive units constitute the flowers. Flowering and flowers play an important role in all seed crops, yield is dependent largely upon the basic reproductive units available. Proteomic analysis reveals the translational products of gene expression of plant during flowering stage. Analysis of proteins is a direct approach to define the function of their associated genes as it linked to genome sequence information, which is important for functional genomics. There are scanty reports of proteome analysis that focus on the study during flower development of peanut genotype (Kottapalli et al., 2008; Liang et al., 2006).

Production of high-quality protein samples is the critical initial step for proteomic analysis. Although numerous of the sample preparation methods had been reported, TCA/acetone precipitation was still a very useful method for minimizing protein degradation/modification and removing interfering compounds such as polysaccharides, polyphenols, pigments and lipids (Saravanan and Rose, 2004; Manadas et al., 2006). However, the precipitated proteins, especially those from recalcitrant tissues, were difficult to resolubilize (Gorg et al., 2004; Carpentier et al., 2005). Repeated precipitation in TCA/acetone presumably causes aberrant and irreversible protein refolding and aggregation. This always results in the loss of certain groups of proteins such as membrane proteins or other hydrophobic proteins and hard-to-obtain well-resolved 2DE maps.
To increase the solubility of precipitated proteins, some chemicals such as chaotropes (urea and thiourea), surfactants (CHAPS) (Valcu and Schlink, 2006), 3-(4-heptyl) phenyl 3-hydroxypropyl dimethylammonio propane sulfonate $(\mathrm{C} 7 \mathrm{BzO})$, SDS (Wang et $a l ., 2006)$ and reductants (b-mercaptoethanol, DTT, tributylphosphane (TBP) (Ruan and wan, 2007; Gomez- Vidal et al., 2008) were added to lysis buffer to break hydrogen bonds, discharge hydrophobic interaction and diminish disulfide bridges. Several physicalaided resolubilization procedures such as sonication and repeated freeze-thaw (Hopkinson et al., 2005) were also reported. However, these methods were time and labor consuming and the rate of resolubilization depended on given plant tissues and skill of researcher (Zhang et al., 2011).

Here, we describe an effective and all-purpose application protocol for protein extraction andtwo-dimensional gel electrophoresis (2DE) analysis from Groundnut (Arachis hypogaea ssp. Virginia) tissues, specifically flower development tissues.

\section{Materials and Methods}

\section{Plant materials}

Gujarat Junagadh Groundnut-22 (GJG-22) genotype of groundnut (Arachis hypogaea ssp. Virginia) was collected for study based on new released variety from "Oil Seed Research Station" of Junagadh Agricultural University, Junagadh, Gujarat, India. Groundnut plants were grown in a net house. A total 12 tissue samples was collected, including nine vegetative tissues and three stages of flower development. Flower bud, open flower and peg are denoted as Stage 1, Stage 2 and Stage 3 respectively. At least three biological replicates were collected for each tissue sample. Each stage of plant included samples were collected; First tetra foliate leaf (UL), 
Last tetra foliate leaf (LL) and Main internode bearing primary branch(S). Three stages each from flower bud, flower and peg development were frozen in liquid nitrogen immediately after harvest and stored at $-80^{\circ} \mathrm{C}$ prior to protein extraction.

\section{Protein extraction}

Protein extracts were prepared in biological triplicates for each developmental stage. For protein extraction, $1 \mathrm{gm}$ of each plant tissues were used. Grind fresh/frozen plant tissues into fine powder in liquid nitrogen, add icecold TCA/acetone (containing $0.07 \% \mathrm{v} / \mathrm{v} \beta$ mercaptoethanol, $5 \mathrm{ml} / \mathrm{g}$ tissue) and transfer this mixture into a centrifuge tube. Place the tube on ice for $5 \mathrm{~min}$. Centrifuge at $10000 \times \mathrm{g}$ for $5 \mathrm{~min}$ at $4^{0} \mathrm{C}$ and discard the supernatant. Repeat this step until a clear supernatant is achieved. Wash the pellet with $1.5 \mathrm{ml}$ ice-cold acetone twice. Invert the tube on a clean piece of absorbent paper to drain the access acetone. Then add phenol (containing 0.5\% w/v DTT, $2 \mathrm{ml} / \mathrm{g}$ tissue) and mix thoroughly, place the tube at RT for $10 \mathrm{~min}$.

Centrifuge at $10000 \times \mathrm{g}$ for $5 \mathrm{~min}$ at $4^{0} \mathrm{C}$ and transfer the supernatant to a new tube. Repeat this procedure thrice and put the supernatant together. Add five volumes of cold methanol (containing $0.1 \mathrm{M}$ ammonium acetate) to the collected phenol, mix thoroughly and keep at $20^{\circ} \mathrm{C}$ for at least $10 \mathrm{~min}$ to precipitate the protein. Centrifuge at $10000 \times \mathrm{g}$ for $10 \mathrm{~min}$ at $4^{0} \mathrm{C}$ and discard the supernatant carefully. Add $1 \mathrm{ml}$ pre ice-cold methanol to wash the pellet, centrifuge at $10000 \times \mathrm{g}$ for $5 \mathrm{~min}$ at $4^{0} \mathrm{C}$ and discard the supernatant. Repeat thisprocedure thrice to remove remaining ammonium acetate and phenol.

Freeze-dry the pellet; the product can be stored at $-80^{\circ} \mathrm{C}$ or used directly for SDSPAGE and IEF. Protein concentration was determined using the 2D-Quanti Kit (GE-
Healthcare $^{\circledR}$ ), with bovine serum albumin (BSA) as standard.

\section{Two-dimensional PAGE electrophoresis}

All two dimension (2DE) procedure was followed as GE health care 2D manual and standard method adopted by (Jiang et al., 2008 and Han et al., 2009). The each 12 samples were diluted with a rehydration buffer $(8 \mathrm{M}$ urea, 2\% CHAPS, 10\% glycerol, $1 \%$ bromophenol blue, 0.5\% IPG-buffer, $0.28 \%$ DTT) to $50-100 \mu \mathrm{g}$ (silver staining) or $300-$ $350 \mu \mathrm{g}$ protein (CBB staining) per 100 or $150 \mu \mathrm{L}$, respectively, and was applied via anodic cup loading. The strips of $24 \mathrm{~cm}$ and pH 4-7(GE Healthcare ${ }^{\circledR}$ ) were rehydrated for at least $10-20 \mathrm{~h}$ in $400 \mu \mathrm{L}$ rehydration buffer. IEF was carried out on the EttanIPGphor 3 (GE Healthcare ${ }^{\circledR}$ ) at $20^{\circ} \mathrm{C}$ with current limit $50 \mathrm{~mA} /$ strip: $1 \mathrm{~h}$ at $200 \mathrm{~V}, 7 \mathrm{~h}$ at $500 \mathrm{~V}, 1 \mathrm{~h}$ at $1000 \mathrm{v}, 8 \mathrm{~h}$ at $8000 \mathrm{~V}$ (gradient), $5 \mathrm{~h}$ at 8000 $\mathrm{V}$, and $4 \mathrm{~h}$ at $5000 \mathrm{~V}$.

The resolution of proteins was further improved when the IEF gels were subjected to electrophoresis in the second dimension in presence of SDS. Prior to second dimension analysis, individual strips were equilibrated for $15 \mathrm{~min}$ in $3 \mathrm{~mL}$ of an SDS equilibration buffer (75mMTris- $\mathrm{HCl}, \mathrm{pH} 8.8,6 \mathrm{M}$ urea, $29.3 \%$ glycerol, $2 \%$ SDS, $0.002 \%$ bromophenol blue) containing DTT (100 $\mathrm{mg} / 10 \mathrm{ml}$ ), followed by $15 \mathrm{~min}$ in a $3 \mathrm{~mL}$ equilibration buffer containing iodoacetamide $(250 \mathrm{mg} / 10 \mathrm{ml})$.

The second dimension was performed on $12 \%$ SDSPAGE gels $(1 \mathrm{~mm} \times 18 \mathrm{~cm} \times 20 \mathrm{~cm})$ using a Protean II system (Bio-Rad®) coupled to a Multi Temp III Thermostatic Circulator (GE-Healthcare ${ }^{\circledR}$ ) cooling bath. Running was set at $80 \mathrm{v}$ for 2020 minutes until the sample travels through the IPG strip into separating gel and $150 \mathrm{~V}$ until the dye reached the bottom of the gel. 
Protein visualization, image analysis and quantification

The gels were then stained with Bio-Safe Coomassie brilliant blue Stain G-250 (BioRad), according to Neuhoff et al., (1988).The gels were kept in staining solution $(0.1 \%$ Coomassie brilliant blue G 250, 40\% methanol,10\% Acetic acid and 50\% distilled water) for overnight. Gels were repetitive destained with destaining solution (40\% methanol and 10\% Acetic acid and 50\% Distilled water) for until the clear protein visualization. Stained gels were scanned and calibrated with Typhoon FLA Scanner. Image analysis was performed with Platinum Master software (GE healthcare). Spot detection was realized without spot editing. The spots were quantified using the \%volume criterion.

\section{Results and Discussion}

2-DE analysis of the different stages at flower development in Groundnut (Arachishypogaea ssp. Virginia)permitted characterizing protein dynamics involved in flower development, disclosing differential metabolism with specific protein, differential expression at each stage, and those in common during the developmental process to achieve a better protein profile of each developmental stages.

The result of study showed that total 9193 spots were detected in software analysis. Out of 9193 spots, 3342 spots in stage 1 (bud stage) and 3864 spots in stage 2 (flower stage) and 1987 spots in stage 3 (peg stage) were reproducibly detected. 75 spots, 194 spots and 170 spots were matched in different stages 1 , 2 and 3 respectively. The molecular masses of matched spots were identified with the range of $23 \mathrm{KDa}$ to $312 \mathrm{KDa}$ with $\mathrm{pH}$ from 4.00 to 6.76 (Table 1). Some protein spots indicated on the comparative 3-D graphs were showed significantly differentiated the relative expression level between samples (Figure 1).
Many spots were shown the significant at different level of expression (Up regulation and down regulation) in all different samples.

Out of 9193 spots, total 3030 spots found between $\mathrm{pH} 4$ to $\mathrm{pH} 5.240$ spots in UL1, 354 spots in bud, 184 spots in LL1 and 232 spots in $\mathrm{S} 1$ and M.W from $24 \mathrm{KDa}$ to $302 \mathrm{KDa}$ in stage 1, 459 spots in UL2, 292 spots in flower, 296 spots in LL2 and 306 spots in S2 and M.W from $24 \mathrm{KDa}$ to $310 \mathrm{KDa}$ in stage 2 and 175 spots in UL3, 45 spots in peg, 173 spots in LL3 and 274 spots in S3 and M.W from 28 $\mathrm{KDa}$ to $265 \mathrm{KDa}$ in stage 3 (Table 1).

Total 2750 spots found between $\mathrm{pH} 5$ to $\mathrm{pH} 6$. There were 301 spots in bud, 222 spots in LL1 and 225 spots in S1 and M.W from $24 \mathrm{KDa}$ to $304 \mathrm{KDa}$ in stage 1,379 spots in UL2, 249 spots in flower, 218 spots in LL2 and 288 spots in S2 and M.W from $23 \mathrm{KDa}$ to 312 KDa in stage 2 and 163 spots in UL3, 68 spots in peg, 195 spots in LL3 and 217 spots in S3 and M.W from $28 \mathrm{KDa}$ to $275 \mathrm{KDa}$ in stage 3; were found between $\mathrm{pH} 5$ to $\mathrm{pH} 6$. Out of 9193 spots, total 2750 spots found between $\mathrm{pH}$ 5 to $\mathrm{pH} 6$ (Table 1).

Total 3413 spots found between $\mathrm{pH} 6$ to $\mathrm{pH} 7$. 292 spots in UL1, 496 spots in bud, 301 spots in LL1 and 270 spots in S1 and M.W from 25 $\mathrm{KDa}$ to $304 \mathrm{KDa}$ in stage 1, 435 spots in UL2, 319 spots in flower, 261 spots in LL2 and 362 spots in S2 and M.W from $24 \mathrm{KDa}$ to 312 KDa in stage 2 and 138 spots in UL3, 75 spots in peg, 220 spots in LL3 and 244 spots in S3 and M.W from $28 \mathrm{KDa}$ to $276 \mathrm{KDa}$ in stage 3 (Table 1).

In protein profiling, maximum (3413) spots were found between $\mathrm{pH} 6$ to 7 and minimum (2750) spots were found between pH 5 to 6 . But highest number of up regulated spots was found between $\mathrm{pH} 6$ to 7. So, it appears that maximum growth and development responsive protein spots were lies near 6-7 $\mathrm{pH}$ range. 
Fig.1 2DE analysis of 12\% PAGE with $\mathrm{pH}$ 4-7 gradient strips were stained using CBB R 250 of groundnut samples. A1: Bud, A2: Lower leaf-1, A3: Stem-1, A4: Upper leaf-1, B1: Flower, B2: Lower leaf-2, B3: Stem-2, B4: Upper leaf-2, C1: Peg, C2: Lower leaf-3, C3: Stem-3, C4: Upper leaf-3
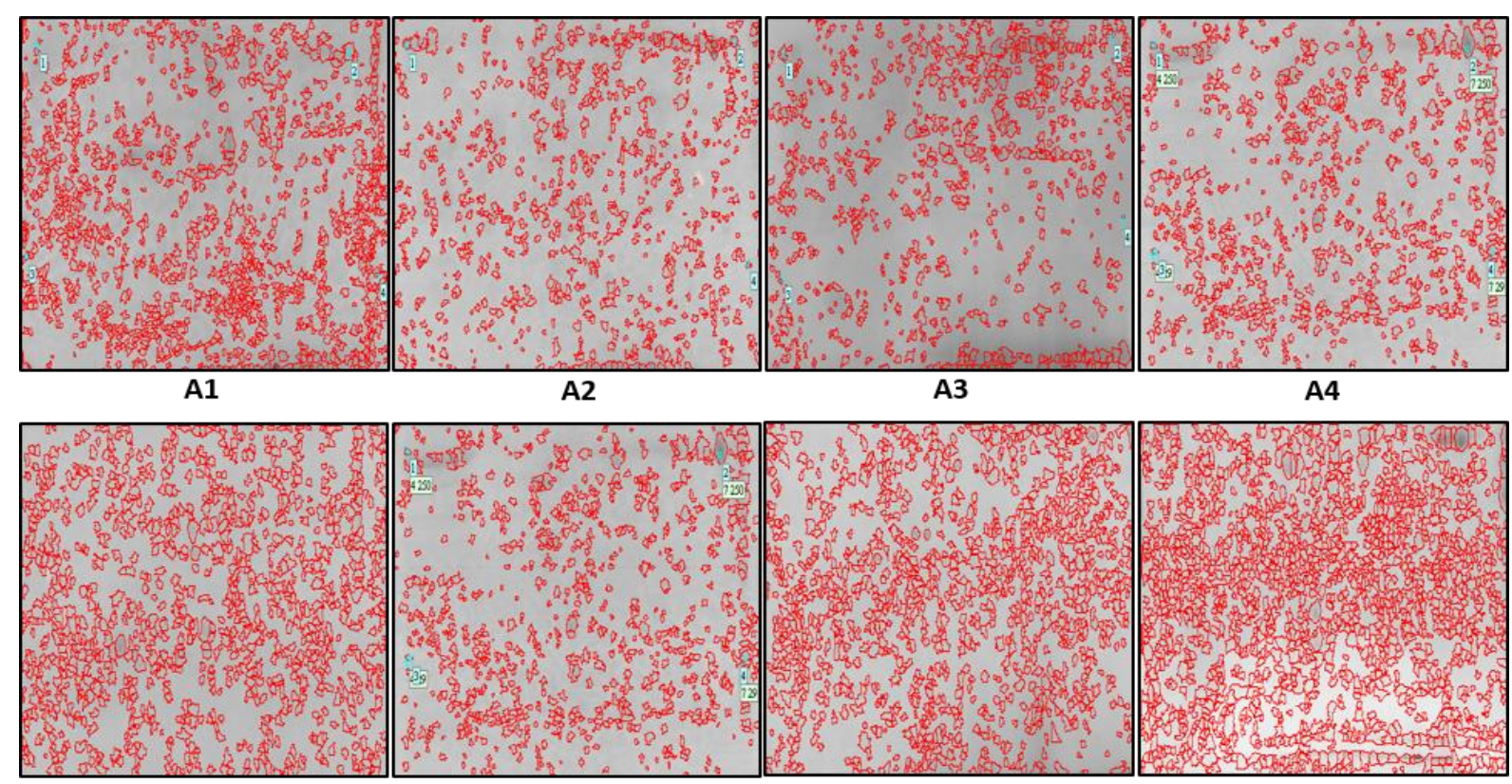

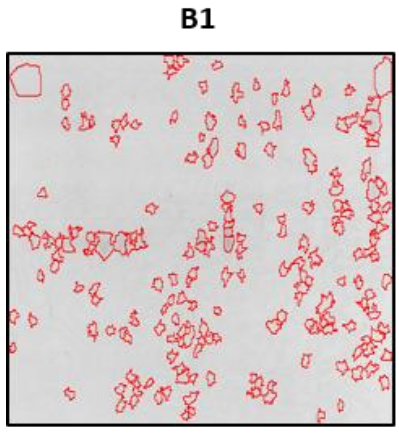

C1

\section{B2}

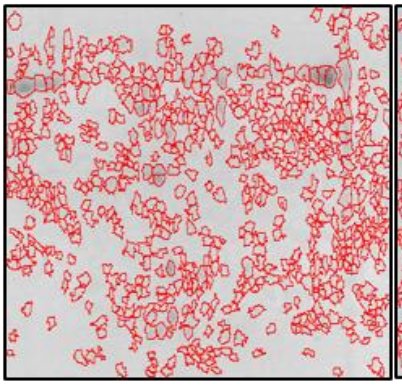

C2
B3

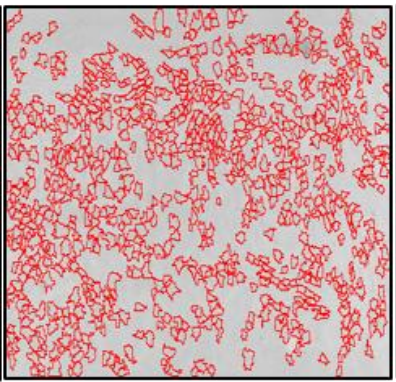

C3
B4

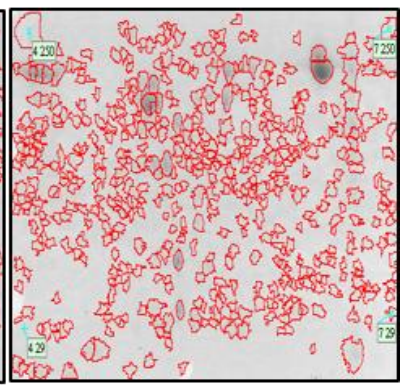

C4

Table.1 Protein spots with PI group and molecular weight ranges of different samples

\begin{tabular}{|c|c|c|c|c|c|c|c|c|c|c|c|c|c|}
\hline \multirow[t]{2}{*}{ PI Range } & \multicolumn{12}{|c|}{ No. of spots } & \multirow{2}{*}{$\begin{array}{l}\text { Total } \\
\text { no. of } \\
\text { Spots }\end{array}$} \\
\hline & UL1 & BUD & LL1 & S1 & UL2 & FLOWER & LL2 & S2 & UL3 & PEG & LL3 & S3 & \\
\hline PI (4-5) & 240 & 354 & 184 & 232 & 459 & 292 & 296 & 306 & 175 & 45 & 173 & 274 & \multirow[t]{2}{*}{3030} \\
\hline MW & $\begin{array}{l}24- \\
301\end{array}$ & $\begin{array}{l}24- \\
302\end{array}$ & $\begin{array}{l}24- \\
290\end{array}$ & $\begin{array}{l}24- \\
298\end{array}$ & $\begin{array}{l}23- \\
308\end{array}$ & $23-295$ & $24-310$ & $\begin{array}{l}24- \\
312\end{array}$ & $\begin{array}{l}28- \\
253\end{array}$ & $\begin{array}{l}28- \\
240\end{array}$ & $\begin{array}{l}28- \\
257\end{array}$ & $27-265$ & \\
\hline PI (5-6) & 225 & 301 & 222 & 225 & 379 & 249 & 218 & 288 & 163 & 68 & 195 & 217 & \multirow[t]{2}{*}{2750} \\
\hline MW & $\begin{array}{l}24- \\
285\end{array}$ & $\begin{array}{l}24- \\
304\end{array}$ & $\begin{array}{l}24- \\
302\end{array}$ & $\begin{array}{l}24- \\
301\end{array}$ & $\begin{array}{l}23- \\
312\end{array}$ & $23-310$ & $23-312$ & $\begin{array}{l}23- \\
310\end{array}$ & $\begin{array}{l}27- \\
265\end{array}$ & $\begin{array}{l}28- \\
275\end{array}$ & $\begin{array}{l}27- \\
243\end{array}$ & $27-272$ & \\
\hline PI (6-7) & 292 & 496 & 301 & 270 & 435 & 319 & 261 & 362 & 138 & 75 & 220 & 244 & \multirow[t]{2}{*}{3413} \\
\hline MW & $\begin{array}{l}24- \\
304\end{array}$ & $\begin{array}{l}24- \\
294\end{array}$ & $\begin{array}{l}24- \\
288\end{array}$ & $\begin{array}{l}25- \\
285\end{array}$ & $\begin{array}{l}24- \\
312\end{array}$ & $24-293$ & $24-310$ & $\begin{array}{l}23- \\
312\end{array}$ & $\begin{array}{l}28- \\
250\end{array}$ & $\begin{array}{l}27- \\
245\end{array}$ & $\begin{array}{l}28- \\
276\end{array}$ & $28-266$ & \\
\hline $\begin{array}{l}\text { Total } \\
\text { Spots }\end{array}$ & 757 & 1151 & 707 & 727 & 1273 & 860 & 775 & 956 & 476 & 188 & 588 & 735 & 9193 \\
\hline
\end{tabular}


Proteomic technology is a useful approach for identifying proteins in plants (Yang et al., 2009; Yang et al., 2007; Hossain et al., 2013; Kosova et al., 2011; Li et al., 2013). Recently, a number of proteins that are differentially expressed between peanut aerial gynophores, subterranean gynophores, and early swelling pods, were identified using two-dimensional electrophoresis combined with mass spectrometry (Zhu et al., 2013; Sun et al., 2013). In the current study, we performed $2 \mathrm{DE}$ to provide a comprehensive overview of the proteome profile at flower development stages from peanut. Compared with traditional approaches, fractionation prior to LC-MS/MS analysis significantly increased the number of identified proteins and individual protein coverage (Das et al., 2010; Wang, et al., 2010). We successfully spotted a total of 9193 proteins in peanut at different flower developmental stages. Out of 9193, 3342 at bud developed stage, 3864 at flower development stage and 1987 at peg formation stage is reported. In contrast to other aboveground organs of peanut, the aerial gynophores grow downwards to the ground. Proteins that play positive roles bud to peg formation to final pod formation. Itwas reported that the $\mathrm{ABC}$ transporters, heat shock proteins, microtubules, and microtubuleassociated proteins play important roles in the plant's development (Collings et al., 1998; Zupanska et al., 2013).

Our analysis of proteome data provided useful information about the mechanism controlling various flower developmental stages. This proteome analysis is first time reported in flower development stage in groundnut. In proteomic analysis, higher protein spots with the different $\mathrm{pI}$ range recorded. Out of these spots apart from differentially expressed spots covers large intensity and based on these many spots up and down regulated at bud, flower and peg stages of groundnut. This investigation facilitated the extraction of high- quality protein samples suitable for $2 \mathrm{DE}-$ electrophoretic analysis in a wide range of routine plant tissues and recalcitrant plant tissues. And also give the idea for further study on identification of protein on the basis of this proteome analysis.

\section{Acknowledgments}

We (authors) express our genuine appreciations to Department of Biotechnology, College of Agriculture, Junagadh Agricultural University, Junagadh for the financial assistance and providing facilities to carry out the present investigation.

\section{References}

Carpentier, S. C., Witters, E., Laukens, K., Deckers, P., Swennen, R., and Panis, B. 2005. Preparation of protein extracts from recalcitrant plant tissues: An evaluation of different methods for two- dimensional gel electrophoresis analysis. Proteomics. 5(10): 2497-2507.

Cobb, W. Y., and Johnson, B. R. 1973. Physiochemical properties of peanut. In Peanuts: Culture and Uses. American Peanut Research and Education Society. pp. 209-263.

Collings, D. A., Winter, H., Wyatt, S. E., and Allen, N. S. 1998. Growth dynamics and cytoskeleton organization during stem maturation and gravity-induced stem bending in Zeamays L. Planta. 207(2): 246-258.

Das, S., Bosley, A. D., Ye, X., Chan, K. C., Chu, I., Green, J. E.,Issaq, H. J., Veenstra, T. D., and Andresson, T. 2010. Comparison of strong cation exchange and SDS-PAGE fractionation for analysis of multiprotein complexes. Journal of proteome research. 9(12): 6696-6704.

Gomez- Vidal, S., Tena, M., Lopez- Llorca, L. V., and Salinas, J. 2008. Protein 
extraction from Phoenix dactylifera L. leaves, a recalcitrant material, for two- dimensional electrophoresis. Electrophoresis. 29(2): 448-456.

Gorg, A., Weiss, W., and Dunn, M. J. 2004. Current two- dimensional electrophoresis technology for proteomics. Proteomics. 4(12): $3665-$ 3685 .

Granier, F. 1988. Extraction of plant proteins for two- dimensional electrophoresis. Electrophoresis. 9(11): 712-718.

Hopkinson, A., McIntosh, R. S., Layfield, R., Keyte, J., Dua, H. S., and Tighe, P. J. 2005. Optimised two- dimensional electrophoresis procedures for the protein characterisation of structural tissues. Proteomics. 5(7): 1967-1979.

Hossain, Z., Khatoon, A., and Komatsu, S. 2013. Soybean proteomics for unraveling abiotic stress response mechanism. Journal of proteome research. 12(11): 4670-4684.

Kosova, K., Vítamvas, P., Prasil, I. T., and Renaut, J. 2011. Plant proteome changes under abiotic stresscontribution of proteomics studies to understanding plant stress response. Journal of proteomics. 74(8): 1301-1322.

Kottapalli, K. R., Payton, P., Rakwal, R., Agrawal, G.K., Shibato, J., Burow, M., and Puppala, N. 2008. Proteomics analysis of mature seed of four peanut cultivars using two-dimensional gel electrophoresis reveals distinct differential expression of storage, antinutritional, and allergenic proteins. Plant Science. 175(3): 321-329.

Li, X., Bai, T., Li, Y., Ruan, X., and Li, H. 2013. Proteomic analysis of Fusarium oxysporum f. sp. cubense tropical race 4-inoculated response to Fusarium wilts in the banana root cells. Proteome science. 11(1): 41.

Liang, X. Q., Luo, M., Holbrook, C. C., and
Guo, B. Z. 2006. Storage protein profiles in Spanish and runner market type peanuts and potential markers. BMC Plant Biology. 6(1): 24.

Manadas, B. J., Vougas, K., Fountoulakis, M., and Duarte, C. B. 2006. Sample sonication after trichloroacetic acid precipitation increases protein recovery from cultured hippocampal neurons, and improves resolution and reproducibility in two- dimensional gel electrophoresis. Electrophoresis. 27(9): 1825-1831.

Neuhoff, V., Arold, N., Taube, D., and Ehrhardt, W. 1988. Improved staining of proteins in polyacrylamide gels including isoelectric focusing gels with clear background at nanogram sensitivity using Coomassie Brilliant Blue G- 250 and R- 250. Electrophoresis. 9(6): 255-262. Reddy, T. Y., Reddy, V.R., and Anbumozhi, V. 2003. Physiological responses of groundnut (Arachis hypogea L.) to drought stress and its amelioration: a critical review. Plant growth regulation. 41(1): 75-88.

Ruan, Y., and Wan, M. 2007. An optimized procedure for solubilization, reduction, and transfer of human breast cancer membrane- enriched fraction by 2- DE. Electrophoresis. 28(18): 33333340.

Saravanan, R. S., and Rose, J. K. 2004. A critical evaluation of sample extraction techniques for enhanced proteomic analysis of recalcitrant plant tissues. Proteomics. 4(9): 2522-2532.

Sun, Y., Wang, Q., Li, Z., Hou, L., Dai, S., and Liu, W. 2013. Comparative proteomics of peanut gynophore development under dark and mechanical stimulation. Journal of proteome research. 12(12): 5502-5511.

Tsugita, A., and Kamo, M. 1999. 2-D electrophoresis of plant 
proteins. Methods in Molecular Biology-Clifton Then Totowa. 112, 9598.

Valcu, C. M., and Schlink, K. 2006. Efficient extraction of proteins from woody plant samples for two-dimensional electrophoresis. Proteomics. 6, 41664175.

Wang, T. Zhang, E. Chen, X. Li, L., and Liang, X. 2010. Identification of seed proteins associated with resistance to pre-harvested aflatoxin contamination in peanut (Arachis hypogaea L). BMC Plant Biology. 10(1): 267.

Wang, W., Vignani, R., Scali, M., and Cresti, M. 2006. A universal and rapid protocol for protein extraction from recalcitrant plant tissues for proteomic analysis. Electrophoresis. 27(13): 27822786.

Yang, M. F., Liu, Y. J., Liu, Y., Chen, H., Chen, F., and Shen, S. H. 2009. Proteomic analysis of oil mobilization in seed germination and post germination development of Jatropha curcas. Journal of proteome research. 8(3): 1441-1451.

Yang, P., Li, X., Wang, X., Chen, H., Chen, F., and Shen, S. 2007. Proteomic analysis of rice (Oryza sativa) seeds during germination. Proteomics. 7(18): 3358-3368.

Zhang, E., Chen, X., and Liang, X. 2011. Resolubilization of TCA precipitated plant proteins for 2- D electrophoresis. Electrophoresis. 32(6- 7): 696-698.

Zhu, W., Zhang, E., Li, H., Chen, X., Zhu, F., Hong, Y., Liao, B., Liu, S., and Liang, X. 2013. Comparative proteomics analysis of developing peanut aerial and subterranean pods identifies pod swelling related proteins. Journal of proteomics. 91, 172-187.

Zupanska, A. K., Denison, F. C., Ferl, R. J., and Paul, A. L. 2013. Spaceflight engages heat shock protein and other molecular chaperone genes in tissue culture cells of Arabidopsis thaliana. American journal of botany. 100(1): 235-248.

\section{How to cite this article:}

Nimita Umretiya, Hitesh Jasani, Nilam Tulsani, Abhijeeta Nandha and Golakiya, B.A. 2018. Two-Dimensional Gel Electrophoresis of Protein profile from Groundnut (Arachis hypogaea sp. Virginia) at Flower Development Stage. Int.J.Curr.Microbiol.App.Sci. 7(10): 3524-3531. doi: https://doi.org/10.20546/ijcmas.2018.710.407 